\title{
African Democratic Heritage: A Historical Case Study of the Igbo of Nigeria.
}

\author{
D. I. Ajaegbo, Ph.D \\ Department of History \& Strategic Studies, Federal University, Ndufu-Alike Ikwo, PMB 1010, Abakaliki, \\ Ebonyi State, Nigeria.
}

\begin{abstract}
Democracy consists of a set of ideas, principles, practices and procedures which enable the citizens of a given society to govern themselves. It is a system of government in which eligible citizens elect or choose their leaders who enact laws, take decisions and execute programmes and policies for the public good. Democratic and leadership culture is not alien to African societies. Africa has a long tradition of forms or systems of democracy. In traditional Igbo society, a number of democratic institutions, values and norms existed through which the people governed themselves. Traditional authorities were not absolute leaders but governed in consultation with the people. The values of consultation, negotiation, cooperation, compromise and consensus were recognised and applied in the decision making process. This paper critically discussed Igbo democratic heritage and strongly argued that in spite of the severe dislocation of Igbo traditional democratic institutions, values and practices by colonialism, some aspects of democratic traditions have survived and continued to function with vitality and new ideas to date.
\end{abstract}

Key words: democracy, heritage, institutions, consensus.

\section{Introduction}

There are over 250 ethnic groups in Nigeria and the Igbo are one of the three major culture groups in this vast West African country that also has the largest concentration of blacks in the world. Nigeria comprises 36 states and the Federal Capital Territory at Abuja. The majority of the Igbo live in the present south-east states of Nigeria which include Abia, Anambra, Ebonyi, Enugu and Imo. There are also significant and preponderant Igbo populations in Delta and Rivers states. Archaeological artifacts excavated from various parts of the Igbo country suggest that the Nri-Awka-Orlu complex was the heartland of the Igbo and that their dispersal from this axis to occupy their present homeland is of great antiquity, dating back to the era between $2555 \mathrm{BC}$ and $9^{\text {th }}$ century AD (Shaw, 1969; Afigbo, 1981; Anozie, 2002, Chikwendu, 2002). It is also reasonable to suggest that the evolution of Igbo society in social, economic, political, cosmological and religious ideas is of great time depth (Afigbo, 1986).

As the Igbo dispersed and permanent settlements developed, communal living led to the emergence of social, economic and political institutions. From these settlements or communities emerged leaders who became centres of power, authority and government. As Igbo social groups evolved and developed, a dynamic and efficient administrative machinery also developed and functioned to regulate social relations. Thus by the time the Europeans came into contact with the Igbo, the latter had already developed a dynamic and advanced political system founded on an egalitarian and democratic culture. This dynamic political arrangement had helped the people to cohere and survive over the millennia.

\section{The Concept of Democracy}

Democracy is a concept that is often misconstrued, misapplied or misused. Defining democracy has proved elusive and this explains why the concept has no generally accepted definition. The gamut of definitions that abound cuts across cultures and continents and raises fundamental questions on its precise import and application. Hornby (2010: 389) defines democracy as "a system of government in which all the people of a country vote to elect their representatives". In the opinion of Appadorai (2004:137), "democracy may be described as a system of government under which people exercise the governing power either directly or through representatives periodically elected by themselves". In the popular phrase of Abraham Lincoln as cited by the United States Information Agency (USIA) (1991:4) democracy is government "of the people by the people and for the people". Realising that etymologically, democracy was derived from two Greek words demos (people) and crates (government or power), it follows that any definition or practice of democracy in any society must recognise that ultimate power belongs to the people.

It is noteworthy that just as scholars differ in their definitions and perceptions of democracy, there is also no consensus on the pillars or essential principles of democracy. The distinctive characteristics of this form of government differ from one society and age to the other. However, certain criteria define democracy no 
matter the variants of this form of government in history, culture and society. The essential principles of democracy include, majority rule, sovereignty of the people, due process, government predicated on the will and consent of the people, guarantee of basic human rights, free, fair, periodic, competitive and inclusive elections, equality before the law and principle of checks and balances or constitutional limitation of powers of government. Others include the accountability of elected representatives to the electorate, free flow of information and the values of consultation, negotiation, tolerance, cooperation, accommodation, compromise and consensus.

There are two basic categories of democracy namely, direct and representative democracy. In a direct democracy, all eligible adult members of the society directly and actively participate in the decision making process of government. In representative democracy, eligible citizens elect people to take decisions, make laws and execute programmes and policies of government for the public good. It is instructive that because of its popularity, political leaders including dictators, in their attempt to claim popular support or give their regimes the aura of legitimacy, pin democratic labels on their governments. Thus, we hear of military democracy, constitutional democracy, liberal democracy, socialist democracy, representative democracy, participatory democracy, capitalist and popular democracy (Wikipedia, 2013; Maclean \& Macmillan, 2009; Jega, 2007; Appadorai, 2004, \& Ravitch, 1989).

Democracy consists of a set of ideas, principles, practices, programmes, policies and procedures of a given society. Therefore, for any society to be labeled a democracy, our criteria for this type of government would apply to a considerable degree. A democratic society should be founded on a civic culture which Diane Ravitch as cited in USIA (1991:18) refers to "the behaviours, practices and norms that define the ability of a people to govern themselves". It should also be founded on many and varied institutions of the given society. These institutions regulate the conduct and behaviour of both the leadership and followership. Through these institutions, the ruling class directs and controls the affairs and activities of members of the society who in turn use them as avenues for effective and meaningful participation in the government of their societies. Africa has a long history of democratic traditions. Democracy is therefore not alien to the continent. In precolonial Igboland, the people evolved a viable democratic culture. It was a home-grown democracy influenced by the people's culture, history and tradition. A number of indigenous institutions which promoted and sustained democratic norms and values existed. This paper will critically examine how these indigenous institutions, some of which have continued to survive and function with some adjustments to date, promoted democratic values, norms and practices in traditional Igbo society.

\section{Igbo Political Organisation}

Prior to the British advent and formal colonization of Nigeria in 1900, the Igbo had evolved and developed a democratic and advanced political system which enabled the people to control social relationships and promote social and political stability. An effective administrative system functioned to control a wide range of social relations and enforce legal and moral sanctions on members of the society. This effective and dynamic political culture helped the people to survive over the millennia. In most parts of Igboland, there existed what Ifemesia (1979:39) called "village democracies". These consisted of nuclear and extended families, lineages, villages and village groups or towns. Each of these village democracies represented different levels of government, constituted an autonomous democracy and exercised an appreciable level of political, social and economic control. Kinship ties also constituted a potent factor in the political system.

\section{The Nuclear Family}

The nuclear family was the basic unit of social and political organisation. As the bedrock of the society, it consisted of the man, his wives, his married and unmarried sons as well as his unmarried daughters. The household sometimes included servants, domestic slaves, pawns and clientele especially where the man was outstandingly wealthy or militarily famous. The man/father was the political, moral and spiritual head of the nuclear family. He held the family ofo - the Igbo symbol of political authority, law, moral uprightness, truth, justice and the link between the living and the dead. His leadership of the family empowered him to direct its affairs such as taking decisions about the management of the family, especially with regard to good conduct and execution of economic activities. In doing this, however, he naturally consulted some members of his family particularly his senior and responsible sons as well as his trusted wives. It is instructive that political activity at this level of political organization was very low.

\section{The Extended Family or Patrilineage (Umunna)}

This was the next unit of political organisation. The extended family or patrilineage (umunna) was made up of a number of families which traced their patrilineal descent from a common eponymous father. The head of the umunna who also occupied the headship of the most senior paternal household, was the di-okpala the oldest male member or lineage patriarch of the extended family. He presided over the extended family 
which comprised all senior adult males and other influential members of the unit including umuada (married daughters) and other women of considerable age and significance. The di-okpala wielded a lot of power in the administration of family lands, allocation of building sites, solemnization of patrilineage marriages, settlement of disputes, matters of inheritance, offering or performance of sacrifices, presiding over meetings and conduct of external relations (Olisa, 2002; Nwosu, 2002; Falola et al, 1993).

The di-okpala was however not an absolute leader. He took decisions in consultation with other heads of the extended family who constituted the patrilineage assembly. The assembly itself consisted of elders or senior heads of the extended family, titled men and men of valour, wealth and intelligence. This assembly took critical decisions through a process of consultation, dialogue, consensus, cooperation and compromise. Opposition or voices of dissent were tolerated. However, any decision arising from the process of consultation (igba izu) and consensus (nkwekolita) was binding on all members. Sanctions which included fines or ostracism, were imposed on recalcitrant members of the patrilineage.

\section{The Major/Maximal Lineage}

The major or maximal lineage was another level of socio-political organization. This consisted of a number of patrilineages or minimal lineages tracing patrilineal descent from a common putative ancestor. The oldest male of the senior patrilineage was the supreme head of the major lineage. He performed moral, spiritual, economic and political functions. He was a sacred individual whose position or office was associated with many taboos and rituals. Unlike the di-okpala, however, he presided over a large assembly or council of elders made up of senior household males, elders, titled men, professionals, priests and men of honour, wealth and intelligence. The supreme head of the major lineage worked in conjunction with the assembly of a council of elders and advisers to exercise administrative, judicial and political authority. Nwosu (2002:237) asserted that the "amount of legitimacy and loyalty he generated depended on his political sagacity, his administrative skill, his moral probity, the extent of his material wealth, his generosity and the general influence he wielded in the wider community".

\section{The Village-Group Assembly}

The highest level of political organization was the village-group or town assembly. The village group (obodo, mba) was made up of a number of major lineages claiming descent from a common ancestor or different putative ancestors. In some cases, some lineages in the village laid claim to autochthonous origins, that is, the theory of independent creation of either emerging from the ground or falling down from the sky. The members of the village assembly were senior adult males of households, elders, professional hunters, men of integrity, influence, wealth and intelligence, priests of deities, titled men, medicine men and warlords. The village assembly functioned as the highest executive, legislative and judicial authority. It was presided over by a council of elders. In some village groups, the custodian of the ofo presided over the assembly while in some others, this function was executed by the oldest member of the council of elders. It is significant to note that although elders were important political figures, government was not gerontocratic as some scholars had thought. As we had already stated, young men of wealth, intelligence and valour were also important actors in the political process. Moreover, as Isichei (1976:22) observed "not all elderly men had an equal say" in the decision making process. Feckless and feeble-minded elders were ignored or sidelined when vital decisions or actions were to be taken.

The supreme head of the village assembly, whether he occupied this position by virtue of his custodianship of ofo or by age, never took unilateral decisions or acted alone in settling inter-lineage or intervillage disputes, declaration of war, establishing market sites or control and parcellization of communal lands. He enjoyed the respect and commanded the obedience of his ministers especially by virtue of the fact that he was the link between the living and the ancestors. He was a constitutional leader and ipso facto, political, administrative, military and judicial decisions were taken by the collective efforts of the constituent members of the village assembly. Disagreements were resolved by consultation, consensus and compromise - a political action often taken by the assembly caucus variously called ndichie, ndi isi ofo, ndi isi ozo, ndi oka okwu or ndi amala - all translated to mean a small group of wise, courageous, transparent, titled and knowledgeable elders and men of intelligence. The village square (amala, ama nzuko ora) was the common meeting place for enacting laws and taking vital decisions affecting the village group. It was the political, religious and social and commercial centre of the village group.

\section{Social Formations and Democratic Principles and Values}

A number of socio-political institutions existed and functioned to promote democratic principles, norms and values. They included the ozo title institution, spirit-masks or secret societies, age grade associations and umuada. The ozo title was conferred on men of wealth, tact, honour, integrity, honesty, hard work and sound judgement. The ozo title aspirant must also be a free-born of the community, peace-loving, one who had 
the interest of the community at heart and was always willing and ready to contribute to the material progress of the community (Ifemesia, 1979). Slaves (ohu), outcasts (osu), strangers (ndi obia), criminals and men of questionable character (ndi ori, ndi ajo omume) were not allowed to take the ozo title. The ozo title holders constituted the political and religious elite of the community. They were actively involved in the decision making process in both political, social, religious and ritual matters. They also made legislations, arbitrated disputes and took decisions on vital issues affecting the peace, progress, stability and corporate existence of the community or village group. As men of integrity, honour, wisdom and sound judgement and because of their link with the ancestors, their decisions and actions were generally considered fair, objective and impartial.

Masks or masquerades especially spirit-masks (mmanwu, muo) were representatives of the spirit of the dead members of the society. They were instruments of arbitration, a device for discipline, order, entertainment and recreation. They were employed by traditional authorities to recover debts, police the community, discipline unfaithful and recalcitrant wives and enforce the decisions of the elders and the village assembly. Among the functions of age grade associations were the enforcement of the laws, customs and decisions of elders, lineage heads and village councils, maintenance of roads, markets and public squares as well as defence of the territorial integrity of the lineage or village group. To obviate the danger of abuse of power and arbitrary actions, both the masquerades and age grades were controlled by traditional authorities.

The umuada or umuokpu, a powerful association of married daughters, played a vital role in the settlement of disputes between husbands and wives and between lineages and village groups. Their voices were heard and considered and their ideas utilized in decision making processes, in times of war and generally in matters concerning the peace and corporate existence of the lineage groups and stability of the social system. As Ifemesia (1979:91) aptly pointed out, the umuada or umuokpu "collaborated to intervene and stop fights between the men of their natal and their marital homes" and also "prevailed upon the menfolk to adopt certain measures in the interest of women". In some Igbo societies, women who were too advanced in age were initiated into secret societies such as spirit masks (muo) which, as we had stated earlier, were vital instruments of government. Moreover, in some western Igbo communities (in present day Delta State), influential women had committees or councils which enacted legislations for women independently of men. When a dispute involving men and women arose, the council was never ignored. Its members participated actively in resolving the dispute amicably. The leader of the council was also coronated by men to assume the title of omu (Queen). The omu wielded considerable power and influence especially in matters relating to the affairs and interests of women (Basden, 1966; Ifemesia, 1979). Similarly, among the Ohafia often referred to as the Cross River Igbo, Professor Njoku (2000) stated their women had a council of elders who exercised jurisdiction over female matters. The council forced men to reconsider or withdraw any decision which infringed upon the rights of women either by abandoning their husbands' homes en masse or punishing their husbands with starvation. Moreover, the council regulated the behaviour of women and girls; commanding obedience, meting out punishments and collection of fines. Although the status of women were degrading and humiliating in traditional Igbo society, they were not completely a marginalized group or passive actors in the socio-economic and political process or consigned to the private sphere of the home. They enjoyed some degree of access to political participation and representation.

\section{The Question of Segmentary and Centralized Nature of the Igbo Political System}

Some Eurocentric and African writers described African societies as "segmentary", "non-centralized", "unorganized" and "acephalous" (Jones, 1963; Horton, 1976; Falola, Uhomoibhi, Mahadi \& Anyanwu, 1993). They denied the presence of central authority and well organised social and political structure in traditional Igbo society. A corollary of this uninformed and prejudiced view was the absence of any form kingship authority and democratic institutions and values. In pre-colonial Igboland, no community could be said to be non-centralized, stateless or lacking in organised and clearly defined leadership structure. At each level of the political and social systems we had earlier discussed, there was evidence of some degree of centralized authority. No human society can effectively function, cohere and survive if there is no definite leadership apparatus to regulate the behaviour and activities of its members. In some parts of Nigeria, big kingdoms such as Oyo and Benin in the south and the Sokoto Caliphate in the north flourished where political authority was highly centralized. The absence of such big kingdoms in Igboland cannot justify the labels pasted on Igbo societies as acephalous, stateless and segmentary. Ifemesia (1979:74-75) rightly contended that

Whenever a number of individuals or units form a political community anywhere, there must be a certain degree of centralization of authority. No human community is therefore either "amorphous" or "unorganized", indeed such expressions should never be applied to any human society anywhere... The characteristic political organization evolved by the Igbo at any point in time was what they found to be most appropriate to their own physical and psychological conditions.

It is instructive that a few centralized kingdoms like Oyo and Benin kingdoms existed in Igboland and these included Ugwuta, Onitsha, Nri and Aboh (Nzimiro, 1972). And even in these centralized political 
systems, the kings were not absolute monarchs. They were deeply revered and obeyed primarily because of the rituals and sanctity associated with their office and royalty. However, their powers were limited by the democratic values and principle of checks and balances. They could not take arbitrary decisions or they would incur the wrath of their subjects and the gods. They ruled on the advice of their cabinet and any monarch who exhibited tyrannical leadership behaviour or infracted the laws, customs and values of the society could be challenged or even deposed. Thus, there is the Igbo saying that a subject could cover his face with a basket and challenge the decisions or actions of the king (Eze, Obi, Igwe). In the words of Isichei (1976:23) traditional Igbo kings or chiefs "were not absolute, and took decisions in conjunction with titled men, and representatives of other groups. Their decisions could be challenged and their persons deposed". According to Uchendu (1965), domination by a few powerful men was deeply resented because the principle of Igbo social relationship requires a man to speak out his mind freely no matter how hurtful to do so.

Traditional Igbo societies had unwritten constitutions which were based on the customs, traditions and values of the people. In some of these societies, leadership was hereditary and in some cases, the kings or chiefs were chosen using such criteria as age, link with deities and heroic achievement. Unlike the kings of Yorubaland and Hausaland, Igbo kings were constitutional monarchs. Among the traditional Igbo, kingship rested with the people (oha bu eze). Kingship institution is of great antiquity in Igboland. The often repeated view that the Igbo have no kings (Igbo enwe eze) is a historical and out of tune with known facts.

\section{Igbo Democratic Traditions and Colonialism}

The advent of colonial powers in Africa and their subsequent colonization of African states dealt a devastating blow to African indigenous institutions, values and practices. In Igboland, colonialism disrupted and undermined the traditional structures and values of the people which constituted the matrix around which their democratic culture revolved. The lineage structure and values were disregarded and disorganized. The denigration of traditional authorities by the colonial political infrastructure such as native courts resulted in the usurpation of the critical functions of the traditional political elite. The traditional leaders who were made warrant chiefs were subjected to the authority and supervision of British political officers. The chief or Obi who was made a warrant chief was no longer freely accountable to his people but to the political officer who appointed him.

The administration of the community on consensus basis and the checks and balances in the traditional political system were ignored by the colonial officers. Unlike in traditional society where a domineering elder, chief, Obi, Eze or Igwe could be ignored, challenged or removed, Afigbo (1972:256) affirmed that "no group of people could remove or ignore a warrant chief or set aside the orders of the Native Court without incurring the displeasure of the government". Other traditional political functionaries and social formations that operated to promote democratic culture and practices in Igbo society were divested of their political and social roles. For example, the ozo title holders, elders, deities and masquerades were rendered virtually impotent and dramatically declined. The elders and ozo titled men not only lost their traditional legislative and judicial authority but also their power, status and prestige in the society. Age grade system ceased to function as security agencies while masks lost their spiritual power to take disciplinary actions against criminals and offending members of the society. It became illegal for any person or group to obtain justice in any institution or from any individual not established or authorized to dispense justice by the British legal system.

Colonialism fundamentally and radically changed the Igbo traditional political landscape. It made the chiefs, who were protected by the might of the colonial government, to play roles that were unconstitutional and undemocratic to the Igbo. The colonial administration hardly preserved or understood the elaborate checks and balances which characterized traditional political institutions and structures. The traditional organs of government were seriously undermined while the political elite were reduced to a position of insignificance (Anene, 1966; Isichei, 1978; Egboh, 1984).

\section{Continuity and Change}

Although colonialism disrupted and undermined the Igbo traditional democratic institutions and values, some of their basic features have survived and continued to function, albeit in modified forms. As Ottenberg (1963:242) rightly observed;

The Igbo have probably changed the least while changing the most. While many of the formal elements of the social, religious, economic and political structure such as lineages, family groups, age grades and secret societies, have been modified through culture contact, many of the basic patterns of social behaviour such as the emphasis on alternative choices and goals, achievements and competition, and the lack of strong autocratic authority have survived and are part of the newly developing culture.

The extended family, major lineages and village groups are still powerful units of political organisation. The village group assembly have transformed into town unions and operate within the framework of their written constitutions. Leadership positions are not occupied by age or by appointment but generally 
through an electoral process. In most cases, however, one's social status is a determining factor in winning elective offices.

Popular or participatory democracy is still a fact of life. In some communities like Ozubulu in Ekwusigo Local Government Area of Anambra State, dialogue, cooperation, compromise and consensus remain important democratic values. Opposition is tolerated and the fundamental human rights of the citizens are respected. Cases which cannot be settled at the extended family level are sent to the maximal lineage and the village group or town for final adjudication. However, an individual has the option to seek redress in court, an act which in some communities attracts a fine or ostracism.

The traditional rulers enjoy the recognition and patronage of the state governments but they are not absolute monarchs. They still rule in consultation with their cabinet members and the executive bodies of town unions. An overbearing monarch (Eze, Obi or Igwe) can be dethroned either by his subjects or by the state government. The umuada remain a powerful association and instrument of the administrative process. The ozo title and masking institutions have continued to function in modified forms. Finally, it is pertinent to state that because of the supremacy of the constitution of Nigeria, all actions or activities of the citizens, working as individuals or groups, are subject to the law of the land.

\section{Conclusion}

Prior to the conquest, occupation and colonization of the Igbo country by imperial Britain, the people had a number of indigenous democratic institutions which enabled them to organise themselves and create functioning and dynamic social and political systems. Traditional authorities were not absolute leaders but governed in consultation with the people. Village democracies existed. Family and lineage heads, elders, titled men, priests, age grades, women, secret societies, men of wealth, intelligence and valour - all were part of the administrative machinery and contributed to the decision-making process. Thus traditional Igbo political culture was not only essentially representative but also demonstrated a high degree of democratic consultation. The democratic values of dialogue, cooperation, compromise and consensus helped the society to cohere and function. Participatory democratic culture was the rule and pervaded every aspect of the political process. Although majority decisions were binding on every member of the society, minority opinions were heard and accommodated.

The concept and practice of democracy differ from one society to the other. Every democracy also has its own institutions and values. Democratic systems also have their limitations and challenges. This explains why in developed democracies, this system of government is not immune from manipulation because of racial and cultural differences, internal division, political failure and protection of vested interests. The United States of America prides herself on the longevity and enduring tenets and values of her constitution. But even in this epicenter of democratic ideals and principles, equality before the law is a façade. The white majority still uses state institutions to oppress and limit the rights of the minorities especially Africa-Americans. Fifty years after the Martin Luther's famous "I have a Dream" speech, racial profiling is still a fact of life in the US. The practice of true democracy in any human society is difficult because of the great diversity of interests and individuals who want their voices to be heard and their views respected. Democratic institutions, values and practices are not the exclusive inventions of Europe and North America. Democratic institutions in every human society are in a continuous process of evolution in response to the growing and changing needs and aspirations of the given society. The advanced political cultures and systems evolved by African societies helped to sustain their civilizations for many centuries before they came into contact with Europe and America. African states should therefore blend the best in their democratic heritage with the best in Western democratic traditions. The constitution which is the matrix around which every democratic government revolves must be capable of change and adaptation. And as USIA (1991:31) stated "in each society and each generation, the people must perform the work of democracy anew, - taking the principles of the past and applying them to the practices of a new age and a changing society".

\section{References}

[1]. Afigbo, A.E. (1972). The warrant chiefs: Indirect rule in south-eastern Nigeria, 1891-1929. London: Longman.

[2]. Afigbo, A.E. (1981). Ropes of sand: Studies in Igbo history and culture. London: Oxford University Press.

[3]. Afigbo, A.E. (1986). An outline of Igbo history. Owerri: Rada Publishing Company.

[4]. Anozie, F.N. (2002). Archaeology in Igboland: The early prehistory. In G.E.K. Ofomata (Ed). A survey of the Igbo nation. Lagos: Africana Publishers Limited.

[5]. Appadorai, A. (2004). The substance of politics. India: Oxford University Press.

[6]. Basden, G.T. (1966). Niger Ibos. London: Frank Cass \& Co. Ltd.

[7]. Chikwendu, V.E. (2002). Archaeology of Igboland: The later prehistory. In G.E.K. Ofomata (Ed). A survey of the Igbo nation. Lagos: Africana Publishers Limited.

[8]. Falola, T., Uhomoibhi, M., Mahadi, A. \& Anyanwu, U. (1989). History of Nigeria, 1: Nigeria before 1800 AD. London: Longman. [9]. Hornby, A.S. (2010). Oxford advanced learner's dictionary. Oxford: Oxford University Press.

[10]. Horton, R. (1976). Stateless societies in the history of West Africa. In J. Ade Ajayi \& M. Crowder (Eds.). History of West Africa, Vol one. Londone: Longman. 
[11]. http://en.wikipedia.org/wiki/democracy. Retrieved 8th July, 2013.

[12]. Ifemesia, C.C. (1979), Traditional humane living among the Igbo: A historical perspective. Enugu: Fourth Dimension Publishers.

[13]. Isichei, E. (1976). A history of the Igbo people. London: Macmillan Press Ltd.

[14]. Jega, A.M. (2007). Democracy, good governance and development in Nigeria. Ibadan: Spectrum Books Ltd.

[15]. Jones, G.I. (1963). The trading states of the oil rivers: A study of political developments in eastern Nigeria. London: Oxford University Press.

[16]. Maclean, I. \& Mcmillan, A. (2009). The concise Oxford dictionary of politics. Oxford: Oxford University Press.

[17]. Njoku, O.N. (2000). Ohafia: A heroic Igbo society. Ebem Ohafia: Kalu Oyeoku Publishers.

[18]. Nwosu, A. N. (2002). Politics and administration in the Igbo traditional society. In G.E.K. Ofomata (Ed). A survey of the Igbo nation. Lagos: Africana Publishers Limited.

[19]. Nzimiro, I. (1972). Studies in Ibo political systems: Chieftaincy and politics in four niger states. London: Frank Cass.

[20]. Olisa, M. (2002). Igbo traditional political system. In G.E.K. Ofomata (Ed.) A survey of the Igbo nation. Lagos: Africana Publishers Ltd.

[21]. Ottenberg, S. (1963). Ibo receptivity to change in W. Bascom \& M. Herskovits (Eds.) Continuity and change in African cultures. Chicago: University of Chicago Press.

[22]. Ravitch, D. (1989). What is democracy and how it should be taught in the schools. Washington, D.C.: USIA

[23]. Shaw, T. (1969). Igbo-ukwu, eastern Nigeria. In T. Shaw (Ed.) Nigerian prehistory and archaeology. Ibadan: Ibadan University Press.

[24]. Uchendu, V.C. (1965). The Igbo of southeast Nigeria. New York: Holt, Rinehart and Winston Inc.

[25]. United States Information Agency (1991). What is democracy? Washington: USIA 